\section{Egnet standardverk for studenter og leger i psykiatrisk spesialistutdanning}

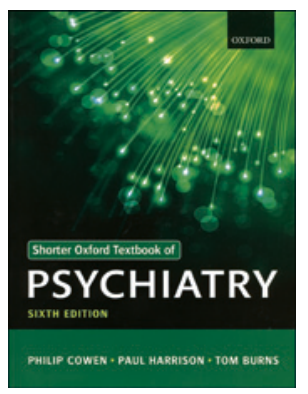

Philip Cowen, Paul Harrison, Tom Burns Shorther Oxford textbook of psychiatry

6.utg. 818 s, tab, ill. Oxford: Oxford University Press, 2012. Pris GBP 60

ISBN 978-0-19-960561-3

Målgruppen er helt eksplisitt leger som tar psykiatrisk spesialistutdanning, men det anføres at også medisinstudenter, primærleger, psykiatere og andre relevante faggrupper vil ha nytte av den. Den mest oppdaterte «secondary level textbook», heter det i vaskeseddelen.

Boken har et tradisjonelt oppsett der man starter med tegn og symptomer på psykiatriske lidelser før klassifisering og kartlegging/diagnostisering. Så følger kapitler om etikk og lovverk og etiologi og evidensbaserte tilnærminger til faget. Deretter gjennomgår forfatterne de enkelte diagnosegruppene før det kommer kapitler om alderspsykiatri, barnepsykiatri, medikamenter og andre fysiske behandlingsmetoder, psykologiske behandlingsmetoder, de psykiatriske helsetjenestene og rettspsykiatri. I alt er det 24 kapitler som forfatterne gjerne innleder med generelle betraktninger og definisjoner, ofte i tillegg til en kortfattet historisk gjennomgang. Det fungerer veldig bra og letter tilegnelsen av stoffet ved at innholdet settes i kontekst. Det stimulerer også til refleksjon og kritisk tenkning, noe som er en styrke.

Figurer er det svært få av, men tabeller og bokser bryter opp det kompakte helhetsinntrykket. Overskriftene er holdt i grønt, noe som gjør dem utydelige, i tillegg til at en noe lik skriftstørrelse på de ulike nivåene kan vanskeliggjøre lesningen.

Med det ambisjonsnivået som forfatterne legger opp til, burde psykiatrisk epidemiologi hatt en bredere dekning enn bare et par sider. Et sentralt begrep som insidens defineres for eksempel ikke, og finnes ikke i indeks selv om det benyttes senere i teksten. Det burde også vært en samlet fremstilling av forebyggende psykiatri, som er et viktig perspektiv i all klinisk virksomhet.

Bruken av begreper som etiologi, årsak og faktor/risikofaktor er uklar, forveksles og burde vært klart definert. Kan en risikofaktor som ikke leder til effekt, være årsak? Neppe, men den kan kanskje inngå i et årsakskompleks.

Kapitlet om bipolar lidelse er mangelfullt. Begrepet brukes synonymt med bipolar lidelse type I. Det er egnet til å tilsløre det bipolare spektrum som det bør reflekteres over i møtet med enhver deprimert pasient. Selv om dette er nevnt, blir det stemoderlig behandlet.

En annen svakhet er at AD/HD kun omtales kortfattet i kapitlet om barnepsykiatri. Lidelsen er prevalent hos voksne, funksjonsnedsettende hos mange, og den oversees i stor grad. Den burde hatt et eget avsnitt under gjennomgangen av psykiske lidelser hos voksne.

Risikoen for en bok som dette, er at den faller mellom flere stoler. På den ene siden er den kanskje for omfattende for medisinstudenter og på den annen side for tynn for den som ønsker å sette seg skikkelig inn i stoffet. Dette kompenseres ved omfattende bruk av litteraturhenvisninger.

På tross av innvendingene - for både studenter og utdanningskandidater i psykiatri anser jeg boken som en egnet basisbok.

\section{Ambisiøs murstein om fattigdom og barnehelse}

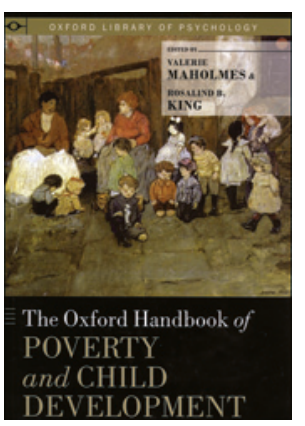

Valerie Maholmes, Rosalind B. King, red

The Oxford handbook of poverty and child development

725 s, tab, ill. Oxford: Oxford University Press, 2012. Pris GBP 95

ISBN 978-0-19-976910-0

Tidlig barndom er den perioden i livet der menneskets fysiske og psykiske helse i sterkest grad påvirkes av levekår og miljø. Epidemiologiske studier har vist at barn som gjennomlever vanskelige oppvekstvilkår, utviser høyere morbiditet og mortalitet gjennom hele sitt livsløp enn det som er tilfelle for deres mer ressurssterke jevnaldrende.

Intensjonen med The Oxford handbook of poverty and child development er i henhold til forordet å gi en vitenskapelig oppdatert gjennomgang av de mekanismene som spiller inn på sammenhengen mellom barns sosioøkonomiske status og helse. Begrepet «Poverty» forstås i denne sammenhengen ikke bare som fravær av økonomiske ressurser. Forfatterne tar også for seg hvordan barnehelsen påvirkes av for eksempel familiestruktur, foreldres sykdom, foreldres yrkesaktivitet eller av oppvekst i minoritetskultur. Det siste kapitlet er viet internasjonale studier av barnehelse ved krig eller humanitær nød.

Dette er et omfattende og vitenskapelig ambisiøst bokverk, og forfatterne henvender seg $\mathrm{i}$ sin form først og fremst til andre forskere i fagfeltet. Det er sju kapitler, hvorav hvert kapittel er sammensatt av fem eller flere frittstående vitenskapelige oversiktsartikler. Boken spenner over vel 700 tettskrevne sider, med kun et fåtall tabeller og illustrasjoner. Språkføringen er stramt akademisk, og hver artikkel er ledsaget av en fyldig referanseliste. Redaktørene har i tillegg valgt å legge litteraturhenvisninger (forfatters etternavn og årstall) inn som del av den løpende teksten, noe som dessverre bidrar til å gjøre innholdet tungt tilgjengelig for leseren.

Når dette er sagt, er tematikken tidvis både relevant og interessant. Kapitlet How poverty gets under the skin er fra mitt ståsted som pediater en fascinerende gjennomgang av de biologiske mekanismene som man tenker seg medierer effekten av vanskelige oppvekstvilkår på senere fysisk og mental helse. I og med at de mange bidragsyterne nesten utelukkende skriver ut fra et nordamerikansk perspektiv, er boken også tankevekkende fra et helse- og sosialpolitisk ståsted. Man tar seg i å lure på i hvor stor grad de økonomiske og sosiale sikkerhetsnettene som eksisterer for barnefamilier i våre europeiske samfunn, klarer å dempe ringvirkningene av fattigdom som man ser i USA?

Boken er altfor tunglest og omfattende til at den lykkes med å selge sitt engasjement for fattige og vanskeligstilte barn til andre enn spesielt interesserte. Den bør imidlertid oppfattes å være et viktig referanseverk for enhver som jobber med barnehelse og samfunnsmedisin fra et helsepolitisk ståsted, eller som planlegger forskningsprosjekter innenfor fagområdet.

Astri M. Lang

Nyfødt intensivavdeling

Oslo universitetssykehus, Rikshospitalet 